\title{
Currently Commercially Available Chemical Sensors Employed for Detection of Volatile Organic Compounds in Outdoor and Indoor Air
}

\author{
Bartosz Szulczyński and Jacek Gębicki * \\ Department of Chemical and Process Engineering, Chemical Faculty, Gdansk University of Technology, \\ 11/12 G. Narutowicza Str., 80-233 Gdańsk, Poland; bartosz.szulczynski@pg.gda.pl \\ * Correspondence: jacek.gebicki@pg.gda.pl; Tel.: +48-58-347-2752 \\ Academic Editors: Ki-Hyun Kim and Abderrahim Lakhouit \\ Received: 5 January 2017; Accepted: 1 March 2017; Published: 6 March 2017
}

\begin{abstract}
The paper presents principle of operation and design of the most popular chemical sensors for measurement of volatile organic compounds (VOCs) in outdoor and indoor air. It describes the sensors for evaluation of explosion risk including pellistors and IR-absorption sensors as well as the sensors for detection of toxic compounds such as electrochemical (amperometric), photoionization and semiconductor with solid electrolyte ones. Commercially available sensors for detection of VOCs and their metrological parameters-measurement range, limit of detection, measurement resolution, sensitivity and response time-were presented. Moreover, development trends and prospects of improvement of the metrological parameters of these sensors were highlighted.
\end{abstract}

Keywords: chemical sensor; measurement; metrological parameters; VOC

\section{Introduction}

Human activity contributes to generation of pollution, the amount and quality of which often exceed utilization abilities of the natural environment. It leads to loss of biosphere balance and frequently to unpredictable results. The anthropogenic sources of pollution can be divided into 4 basic groups:

- $\quad$ energetic connected with mining processes (mines, drawing shafts) and fuel combustion,

- $\quad$ industrial engulfing heavy industry (crude oil processing, metallurgy, cement plants, organic chemistry industry), production and application of solvents, food industry, pharmaceutic industry and so on,

- $\quad$ traffic, road transport (mainly cars), air and water transport,

- $\quad$ municipal, farms, houses, storage and utilization of solid waste and sewage (landfills, treatment plants) [1-4].

Volatile organic compounds (VOCs) constitute an important fraction of gaseous pollutants over urbanized areas, which originates from exhaust gases, evaporation of petroleum products and utilization of organic solvents [5-9]. VOCs take part in many photochemical reactions that yield harmful or even toxic products. Volatile organic compounds can also cause serious health problems as a number of them exhibit toxic, carcinogenic, mutagenic or neurotoxic properties. Moreover, many of them possess malodorous character that can contribute to deterioration of air quality [10-12]. What is more, VOCs are present at different concentration levels in indoor air. People who live in the climatic zone of the Central Europe spend most of their lifetime indoor. A statistic adult spends about $80 \%$ of their life at home, workplace, school, restaurant, cinema, means of public transport, etc. [13-16]. 
Elder people and children spent even more time indoor. Hence, even relatively low concentration of the pollutants present in indoor air can constitute health hazard due to long time of impact. The amount of pollutants present in indoor air increases due to different reasons [17-19]:

- $\quad$ construction of hermetic buildings (preventing energy loss), which do not provide enough air exchange,

- implementation of construction and finish materials with not fully identified properties,

- $\quad$ decreasing of height and volume of rooms.

The World Health Organization (WHO) recognized volatile organic compounds as the most important pollutants of indoor air. Harmless air is defined as the one, in which the total content of VOCs is lower than $100 \mu \mathrm{g} / \mathrm{m}^{3}$. Among ca. 500 volatile compounds identified so far and present in indoor air only a few were proved pathogenic. Nevertheless, many of them are believed to contribute to such symptoms as: allergies, headaches, loss of concentration, drying and irritation of mucous membrane of nose, throat and eyes, etc. [20,21]. A set of such symptoms is named "Sick Building Syndrome". Indoor air quality depends on ambient air (outdoor one) and indoor emitters such as:

- construction materials,

- finish materials (paints, lacquers, wallpapers, floor covering, expanded polystyrene boards),

- burning processes, tobacco smoking,

- cleaning and preservation substances.

The largest group of emitted compounds are hydrocarbons including aromatic ones: benzene, toluene and xylenes. A significant contribution also originates from esters of short-chain organic acids, terpenes, formaldehyde and phenols. However, correct evaluation of outdoor and indoor air is not an easy task. Air is a quite complicated system subjected to changes even in a short period of time. Recently observed dynamic progress in analytical methods and analytical instruments is a basis for obtaining reliable information on indoor and outdoor air condition and quality. However, this progress leads to an increase in the cost of monitoring and air quality evaluation, which significantly limits their widespread application. Hence, alternative methods of acquisition of the information on air quality are being sought. Special attention is paid to sensor techniques [22-24]. According to a definition "chemical sensor" is a device, which changes chemical information from the environment into analytically useful signal. Numerous advantages of the chemical sensors include: low cost of manufacturing, simple design and possibility of miniaturization as well as relatively good metrological parameters such as sensitivity, selectivity, measurement range, linearity or response time. VOCs concentration level in air determines selection of the chemical sensors for their measurement. In the case of measurement of exhaust gases and indoor air at workplace, applicability of the chemical sensors is relatively high due to practical and economic advantages of these sensors.

The authors of this paper want to present up-to-date solutions available on the market as far as the chemical sensors for measurement of volatile organic compounds in outdoor and indoor air are concerned.

\section{Characteristics of the Chemical Sensors for Detection of VOCs}

In the case of commercially available chemical sensors for detection of volatile organic compounds one can distinguish two main approaches: the sensors for identification of explosion risk including thermal sensors (pellistors) and the infrared radiation absorption sensors. The latter group intended for detection of toxic gases belonging to VOCs includes electrochemical, semiconductor with solid electrolyte and PID-type sensors (photoionization detectors) [25,26]. Obviously, the main objective of the manufacturers is elaboration of a sensor with the best selective properties and with the low limit of quantification (LOQ). Figure 1 presents the concentration range of VOCs present in ambient air, indoor air at workplace and in exhaust gases. The figure also shows, which commercially available sensors 
are designated for detection and measurement of VOCs in ambient air, indoor air at workplace and in exhaust gases. It can be observed that the PID-type and electrochemical sensors are characterized by the lowest LOQ values. Design and operation principle of these sensors were described below.

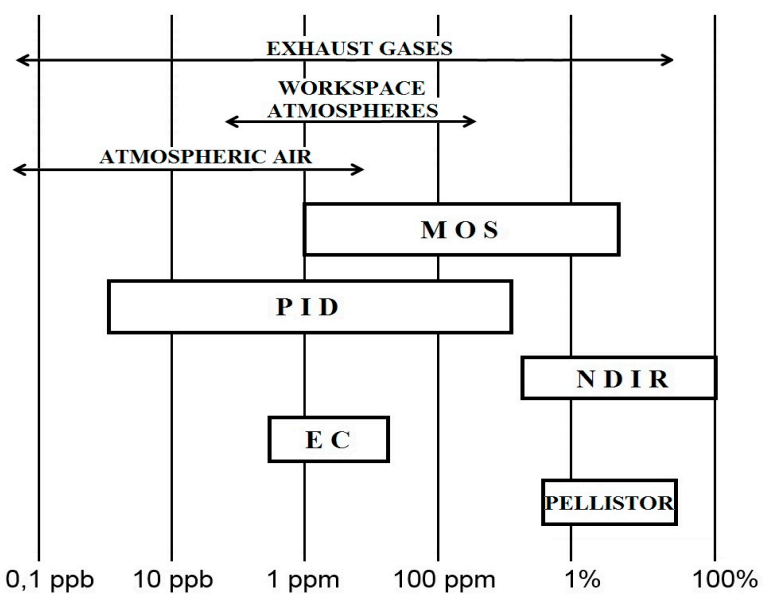

Figure 1. The concentration range of VOCs present in ambient air, indoor air at workplace and in exhaust gases and commercially available sensors are designed for detection and measurement of VOCs. MOS-Metal Oxide Semiconductor, PID—Photoionization Detectors, NDIR-Nondispersive infrared sensors, EC—Electrochemical, PELLISTOR-Thermal sensor.

\subsection{Electrochemical (Amperometric) Sensors}

In these sensors analyte particles diffuse through a membrane (separating gas environment from an internal electrolyte) and the internal electrolyte (most frequently aqueous solution of strong acids or bases, although mixtures with aprotic solvent are also utilized) towards the surface of a working electrode suitably polarized with respect to a reference electrode. Electrochemical reaction occurs at the working electrode, whereas a counter electrode experiences the reaction providing electron balance. A result of the redox reaction is generation of electric current being a sensor signal. This signal is proportional to concentration of the analyte present in direct vicinity of the sensor (gas environment) $[27,28]$. Figure 2 schematically illustrates design of the electrochemical sensor in a three-electrode version with the working (measurement) electrode, counter electrode and reference electrode of constant potential with respect to the working electrode.

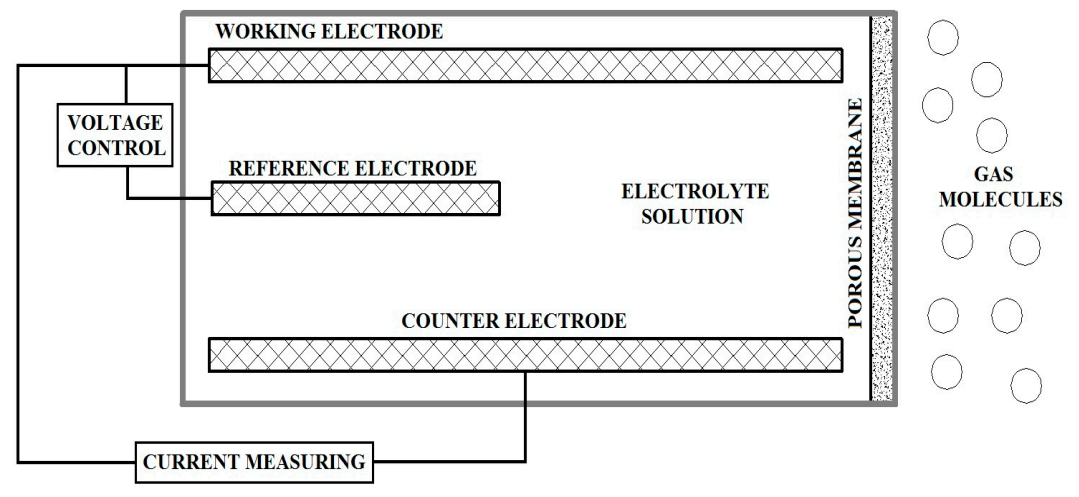

Figure 2. Scheme of electrochemical sensor in a three-electrode version with the measurement electrode, counter electrode and reference electrode.

Table 1 presents commercially available electrochemical (amperometric) sensors by Environmental Sensors Co. intended for measurement toxic compounds in air. 
Table 1. Electrochemical sensors by Environmental Sensors Co. for measurement toxic compounds in air.

\begin{tabular}{cccc}
\hline Pollutants & Range $(\mathbf{p p m})$ & Resolution $(\mathbf{p p m})$ & Response Time (s) \\
\hline ammonia & $0-50$ & 0.5 & 150 \\
carbon monoxide & $0-1000$ & 0.5 & 35 \\
chlorine & $0-20$ & 0.1 & 60 \\
ethylene oxide & $0-20$ & 0.1 & 140 \\
formaldehyde & $0-30$ & 0.01 & 60 \\
glutaraldehyde & $0-20$ & 0.01 & 60 \\
hydrogen sulfide & $0-50$ & 0.1 & 30 \\
nitric oxide & $0-1000$ & 0.5 & 10 \\
nitrogen dioxide & $0-20$ & 0.1 & 35 \\
sulfur dioxide & $0-20$ & 0.1 & 15 \\
\hline
\end{tabular}

\subsection{Metal Oxide Semiconductor Sensors}

In these sensors analyte particles diffuse towards the receptor surface, which is metal oxide (maintained at suitable temperature using heater) where they undergo chemisorption. This interaction results in change of resistance of the receptor element. Two types of metal oxide semiconductors are utilized in measurement practice:

- $\quad$ type $\mathrm{n}$ (for example $\mathrm{ZnO}, \mathrm{SnO}_{2}$ ), which change resistance of the receptor element in the case of reducing gases presence,

- type $\mathrm{p}$ (for instance $\mathrm{NiO}, \mathrm{CoO}$ ), which change resistance of the receptor element in the case of oxidizing gases presence.

The sensing mechanism of semiconducting n-type metal oxides is based on a phenomenon of chemisorption of oxygen contained in air on the metal oxide layer. Adsorbed oxygen molecules trap the electrons from a conducting band of the semiconductor. It results in formation of energetic barriers between the grains of metal oxides, which block a flow of electrons. The consequence is an increase in resistance of the chemically sensitive layer of the sensor. Resistance of the chemically sensitive layer drops when gas molecules of reducing character appear. They react with bound oxygen leading to liberation of electrons. Reverse principle of operation occurs for p-type metal oxides, which identify oxidizing gases. The molecules of gas compounds remove electrons from the chemically sensitive layer, thus forming electron holes (charge carriers).

The process of signal generation (change of resistance) in the semiconductor sensors is not fully recognized. It is complex and consists of a number of co-existing phenomena: diffusion, chemisorption and desorption of gases, catalysed chemical reactions, electric conductivity of semiconductors and electron surface phenomena. The sensor sensitivity depends on:

- thickness of receptor layer and catalytic metal particles placed in it,

- $\quad$ temperature of receptor layer.

The receptor-converter elements of the resistance sensors can be:

- $\quad$ ultrathin (thickness from 5 to $100 \mathrm{~nm}$ )

- $\quad$ thin (thickness from $100 \mathrm{~nm}$ to $1 \mu \mathrm{m}$ ),

- $\quad$ thick (thickness from 1 to $300 \mu \mathrm{m}$ ).

This division has conventional character as it is not the lateral dimension but a method of elaboration that decides about classification into particular group. Desired measurement properties are obtained via surface modification of the receptor-converter element by:

- formation of ultrathin, discontinuous structures,

- deposition of thin layers having compact or microporous internal structure [29,30]. 
The materials used for the modification include metals: Pt, Pd, Ag, Au, V, Ru, Rh, Ti, Co, In and oxides: $\mathrm{SiO}_{2}, \mathrm{Rh}_{2} \mathrm{O}_{3}, \mathrm{RuO}_{2}, \mathrm{Ir}_{2} \mathrm{O}_{3}, \mathrm{TiO}_{x}, \mathrm{CuO}, \mathrm{WO}_{3}, \mathrm{~V}_{2} \mathrm{O}_{5}$.

The mechanism of operation of the semiconductor sensors strongly depends on temperature of the receptor-converter element as this parameter influences on the most important stages of a measurement process. Typical operation temperature of these sensors is within the 500-900 K range. Appropriate temperature is provided by electrical heaters.

The semiconductor sensors with solid electrolyte find a lot of applications in gas analysis. They can be used for measurement of hydrocarbons and their derivatives, alcohols, ethers, ketones, esters, carboxylic acids, nitroalkanes, amines or aromatic compounds [31-34]. Schematic design of the MOS-type sensor is shown in Figure 3.

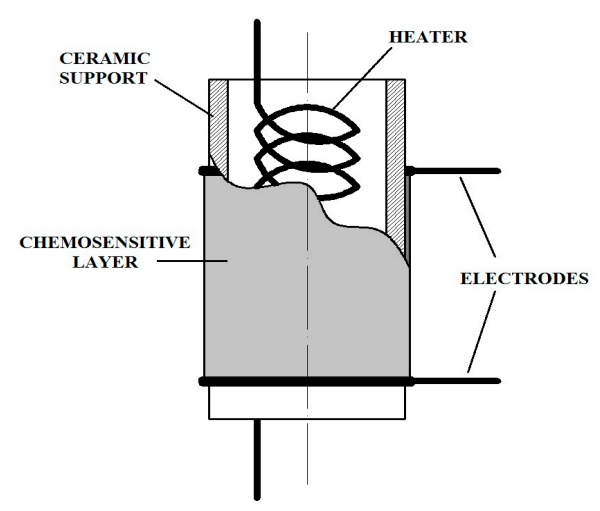

Figure 3. Scheme of MOS-type sensor.

\subsection{Nondispersive Infrared Sensors (NDIR)}

Flammable gases and vapours from the VOCs group are subjected to characteristic absorption of radiation from the infrared range. The ranges of oscillation frequency (wave number) characteristic for selected functional groups of VOCs are presented in Figure 4. The principle of operation of this type of sensor consists in arranging a source of infrared radiation along an optical line with a detector. When an analysed gas appears in a measurement chamber, it absorbs radiation of a particular wavelength and, following the Lambert-Beer law, there is a decrease in radiation reaching the detector, which is converted into electrical signal. Intensity of infrared radiation is diminished as it passes through the measurement cell. This reduction of light intensity is proportional to concentration of the gases or flammable vapours subjected to detection [35,36]. An important element of the sensor is an optical filter, which passes absorbed light of defined wavelength, thus providing selectivity of particular sensor. Some designs possess additional (reference) chamber, which is filled with non-absorbent gas (typically nitrogen). In this case the signal is generated based on a difference in readings from the detectors of both chambers. Figure 5 schematically presents a design of the NDIR-type sensor.

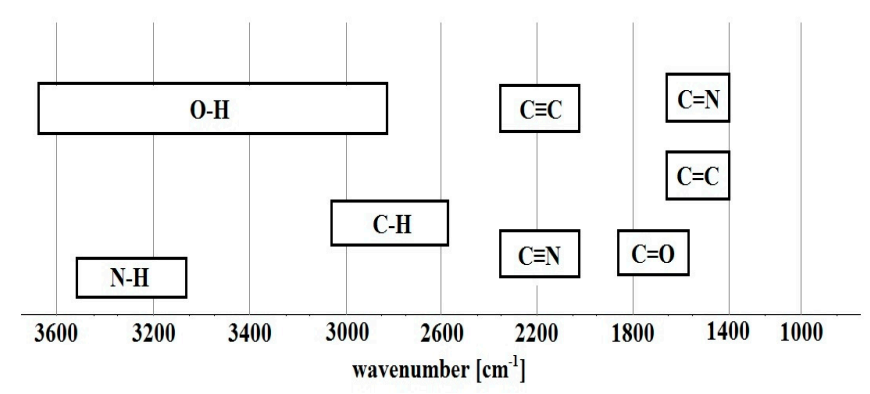

Figure 4. Ranges wave numbers characteristic for selected functional groups of volatile organic compounds. 


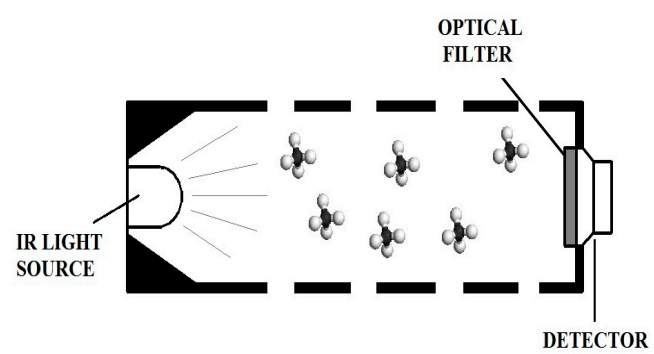

Figure 5. Scheme of NDIR-type sensor.

\subsection{Thermal Sensor (Pellistor)}

A phenomenon of explosion can be initiated in a mixture of flammable gas and air only within precisely defined concentration range. Lower explosion limit (LEL) determines the minimum concentration of the substance, which can react in a rapid combustion process. Upper explosion limit (UEL) describes the maximum amount of the fuel, at which the mixture contains enough oxidizer to initiate the explosion. The values of LEL and UEL differ for various substances and are usually expressed with respect to air. Concentrations of explosive substances below LEL and above UEL allow for safe operation. Table 2 presents the values of LEL for selected substances from the VOCs group [25]. The principle of operation of this type of sensor consists in diffusion of a mixture of air and particular flammable compound through porous sinter towards porous sensor surface. The porous element contains miniature coil made of platinum wire. Electric current flows through a coil made of platinum wire and heats the pellistor up to a few hundred degrees Celsius. The reaction at the catalytic surface releases heat, which increases temperature of the platinum coil, inducing an increase in its resistance. The pellistor is most commonly implemented as one arm of the Wheatstone bridge, the output of which is the final signal. In the case of temperature changes the output bridge signal is proportional to heat of reaction. Increase in temperature is a measure of concentration of flammable gas substance $[25,37,38]$. A scheme of the pellistor design is illustrated in Figure 6.

Table 2. Lower explosion limit for selected VOCs.

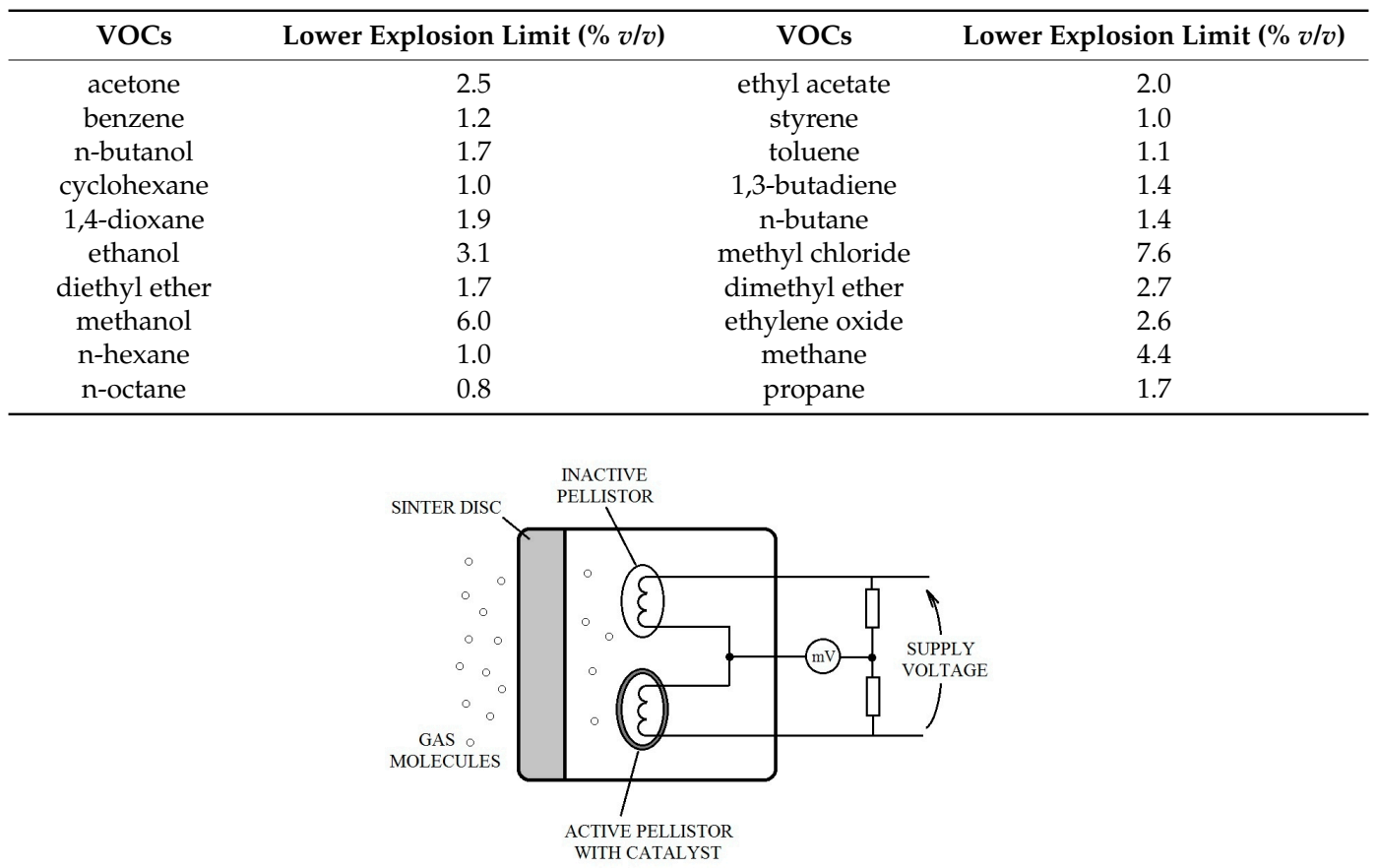

Figure 6. Scheme of pellistor-type sensor. 


\subsection{Photoionization Sensor (PID)}

The principle of operation of the photoionization sensors consists in ionization (decay into charged particles) of neutral molecules of chemical compounds. When diffusing VOCs molecules enter the region of UV lamp impact, they are ionized by photons. Then formed ions are directed between two polarized electrodes. The ions move towards the electrodes in an electric field generated by an electrometer. In this way a current flow is generated, which is then converted into voltage signal. This signal is proportional to concentration of the compounds subjected to ionization. The photoionization sensors utilize electrodeless ultraviolet lamps (wavelength $10-400 \mathrm{~nm}$ ). Operation of the lamp consists in excitation of the filling gas (most often krypton, xenon, radon) via the impact of external electromagnetic field. This type of sensor is most frequently applied for measurement of summary concentration of volatile organic compounds [39-41]. A scheme of the photoionization sensor is presented in Figure 7.

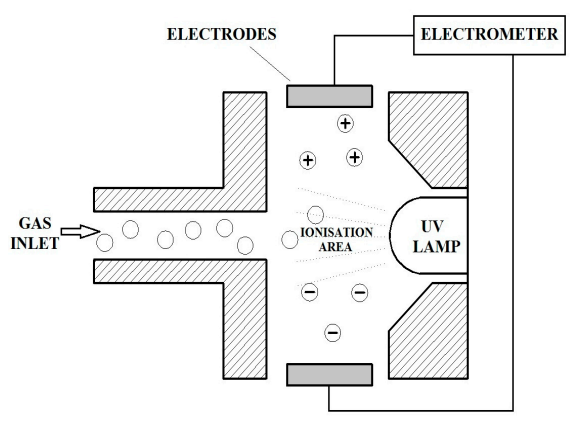

Figure 7. Scheme of photoionization sensor design.

Table 3 shows the main applications of the above described sensors for detecting the VOC.

Table 3. Main applications currently commercially available of sensors for determination of VOC.

\begin{tabular}{|c|c|c|}
\hline Sensor Type & Applications & Compounds \\
\hline MOS & $\begin{array}{ll}- & \text { Urban air monitoring } \\
- & \text { Roadside monitoring } \\
- & \text { Industrial perimeter measurement } \\
- & \text { Indoor Air Quality } \\
- & \text { Smart home \& Internet of Things modules } \\
- & \text { Medical equipment } \\
- & \text { Fire detection } \\
- & \text { Ventilation control/air cleaners }\end{array}$ & $\begin{array}{l}\text { alcohols, aldehydes, aliphatic } \\
\text { hydro-carbons, amines, aromatic } \\
\text { hydro-carbons (petrol vapors, etc.), } \\
\text { carbon oxides, CH4, LPG, ketones, } \\
\text { organic acids. }\end{array}$ \\
\hline PID & $\begin{array}{ll}\text { - } & \text { Industrial hygiene \& safety monitoring } \\
\text { - } & \text { Confined space entry } \\
\text { - } & \text { Soil contamination and remediation } \\
\text { - } & \text { Hazmat sites and spills } \\
\text { - } & \text { Arson investigation } \\
\text { - } & \text { EPA concentration leak detection }\end{array}$ & $\begin{array}{l}\text { VOC's with proper ionisation } \\
\text { potential (isobutylene, } \\
\text { aromatic hydrocarbons) }\end{array}$ \\
\hline NDIR & $\begin{array}{ll}- & \text { Indoor Air Quality } \\
- & \text { Combustion process monitoring } \\
- & \text { Biogas production }\end{array}$ & $\begin{array}{l}\text { infrared absorbing VOC's } \\
\text { (especially methane) }\end{array}$ \\
\hline $\mathrm{EC}$ & $\begin{array}{ll}\text { - } & \text { Breathanalyzer } \\
\text { - } & \text { Environmetnal protection } \\
\text { - } & \text { Odorants monitoring in natural gas applications } \\
\text { - } & \text { Urban and industrial area monitoring } \\
\text { - } & \text { Mobile monitoring applications }\end{array}$ & $\begin{array}{l}\text { ethanol, formaldehyde, } \\
\text { mercaptanes }\end{array}$ \\
\hline PELLISTOR & $\begin{array}{ll}\text { - } & \text { Hydrogen and combustile gas leak detectors } \\
\text { - } & \text { Detectors for fuel cells } \\
\text { - } & \text { Explosive atmosphere monitoring }\end{array}$ & $\begin{array}{l}\text { most combustile gases and } \\
\text { vapours (iso-butane, } \\
\text { propane, methane) }\end{array}$ \\
\hline
\end{tabular}


The literature also provides information about other types of the sensors for VOCs detection in outdoor and indoor air. They include the following sensor types: chemoresistors (conductive polymers), surface acoustic wave, optical, quartz microbalance, FET, hybrid nanostructures. Table 4 presents advantages and disadvantages of these sensors together with the information about a VOC group they are designated.

Obviously, new solutions are still being sought in order to make the sensory techniques attractive and fulfil the customers' requirements. It is also worth to mention the sensor matrixes, also termed electronic noses, which are comprised of different types of chemical sensors. The most frequently utilized sensors include semiconductor, electrochemical and PID-type ones. These devices have been already applied in many fields of human activity including safety, environmental pollution, medicine, work safety regulations, food industry, chemical industry [42-44].

A search for new ways to improve metrological and utility parameters is also evident in the field of electrochemical and semiconductor sensors technology. In case of the semiconductor sensors with solid electrolyte it is proposed to modify the receptor layer via suitable doping and addition of catalysts. The conductometric sensors with a layer of organic conducting polymer operate in a way similar to the semiconductor sensors, change of resistance is a signal of both sensors. Two types of these sensors can be distinguished as far as their structure is concerned: with a composite polymer layer (for instance polypyrrole, graphite dissolved in a polymer matrix serving as an insulator) and with a layer of intrinsically conducting polymers (for example polyaniline, polypyrrole, polythiophene, polyacetylene, poly(phenylvinylene), poly(thienylenevinylene), poly(3,4-ethylenedioxythiophene), poly(N-vinylcarbazone). The sensors of the first type (utilizing the composite layer), as opposed to the MOS-type sensors, can operate at very high humidity and they exhibit linear response to many gas substances in a very wide concentration range. In case of the sensors of the second type (with the layer of intrinsically conducting polymers) the polymers can be doped (type $n$ and type $p$ ) in a way similar to semiconductors. A type of doping results in an increase in the number of charge carriers and a change of polymer chain structure. Both processes cause enhanced mobility of holes or electrons in the polymer depending on the type of doping applied, which significantly contributes to an increase in sensor sensitivity. The advantages of the sensors with a layer of intrinsically conducting polymers include broad selection of suitable conducting polymer and possibility of its doping in order to obtain desired sensor's characteristics [45-50].

Traditional internal electrolyte in the electrochemical sensors is substituted with the ionic liquids, the main advantage of which is a possibility of modification of their physico-chemical properties by selection of suitable cation and anion. These modifications provide broadening of electrochemical durability range, relatively high electrical conductivity and possibility of measurement of volatile organic compounds, which would be impossible or significantly limited in the case of aqueous electrolytes utilization [51,52]. The ionic liquids also found application in conductive polymers sensors and optical sensors. In case of the conductive polymers sensors a function of the ionic liquids is to modify electrical conductivity of a polymer matrix and to provide selective sorption with respect to the air component determined. Suitable selection of the ionic liquid ensures improved sensitivity due to high enough gas/polymer matrix partition coefficient. Sensitivity of the optical sensors depends on a fluorescent dye (or dye mixture) applied and on the polymer matrix, in which the dye is dissolved. Such parameters of the matrix as polarity, hydrophobicity, porosity and expansion tendency have a significant impact on the value of sensor signal. The ionic liquids in the optical sensors influence on change of physico-chemical properties of the polymer matrix, mainly on polarity and sorption properties. 
Table 4. Other chemical sensors used to detection VOC.

\begin{tabular}{|c|c|c|c|}
\hline Sensor Type & Measurand & Advantages/Disadvantages & VOC's \\
\hline $\begin{array}{l}\text { Chemoresistors } \\
\text { (conductive polymers) }\end{array}$ & conductivity & $\begin{array}{l}\text { + low operating temperature } \\
\text { + small } \\
\text { + low power consumption } \\
\text { + cheap } \\
\text { + sensitivity depends on the type of coating } \\
\text { - sensitive to temperature and humidity } \\
\text { - baseline drift (due to polymer instability) } \\
\text { - short lifetime }\end{array}$ & $\begin{array}{l}\text { acetone, acetonitrile, benzene, buthylamine, } \\
\text { cyclohexane, ethanol, hexane, isopropanol, } \\
\text { methanol, methylene chloride, toluene, } \\
\text { xylenes [53-55] }\end{array}$ \\
\hline $\begin{array}{l}\text { Chemoresistors (graphene, } \\
\text { carbon nanotubes composites) }\end{array}$ & conductivity & $\begin{array}{l}\text { + low detection limits } \\
+ \text { fast response } \\
\text { + good sensitivity } \\
\text { - complicated fabrication process } \\
\text { - poor reproducibility }\end{array}$ & $\begin{array}{l}\text { acetone, benzene, chloroform, ethanol, hexane, } \\
\text { isopropanol, methanol, propanol, } \\
\text { trichlotoethylene, toluene, m-xylene [56-60] }\end{array}$ \\
\hline Hybrid nanostructures & depends on the type of sensor & $\begin{array}{l}\text { + low detection limits } \\
\text { + high selectivity } \\
\text { - complicated fabrication process } \\
\text { - poor reproducibility }\end{array}$ & $\begin{array}{l}\text { chloromethane, chloroform, ethanol, } \\
\text { ethylacetate, methanol, octane, toluene [61-65] }\end{array}$ \\
\hline Surface Acoustic Wave & frequency & $\begin{array}{l}\text { + small } \\
\text { + low power consumption } \\
\text { + god sensitivity to various chemicals } \\
\text { + low detection limits } \\
\text { - sensitive to humidity } \\
\text { - large measurement noise } \\
\text { - complicated signal processing system }\end{array}$ & ethanol, octane, toluene $[66,67]$ \\
\hline Optical & change in light parameters & $\begin{array}{l}\text { + portable and simple to use } \\
\text { + possible visual detection } \\
\text { + fast response time } \\
\text { - Can be affected by humidity } \\
\text { - very complex electronics } \\
\text { - short lifetime due to photobleaching }\end{array}$ & $\begin{array}{l}\text { benzene, butane, chlorobenzene, chloroform, } \\
\text { dichloromethane, ethanol, ethyl acetate, } \\
\text { formaldehyde, hexane, isopropanol, methane, } \\
\text { methanol, oct-1-ene, propane, } \\
\text { tetrahydrofurane, toluene, xylene [68-73] }\end{array}$ \\
\hline
\end{tabular}


Table 4. Cont

\begin{tabular}{|c|c|c|c|}
\hline Sensor Type & Measurand & Advantages/Disadvantages & VOC's \\
\hline Quartz Microbalance & mass change & $\begin{array}{l}\text { + low detection limits } \\
+ \text { high sensitivity and selectivity } \\
\text { + fast response } \\
\text { - poor signal-to-noise performance } \\
\text { - complicated signal processing system }\end{array}$ & $\begin{array}{l}\text { acetone, acetonitrile, ethanol, } \\
\text { 3-methyl-1-butanol, 1-octanol, toluene, } \\
\text { p-xylene [74-76] }\end{array}$ \\
\hline FET & threshold voltage change & $\begin{array}{l}\text { + low cost } \\
+ \text { small } \\
\text { + reproducible } \\
\text { - long response time } \\
\text { - baseline drift } \\
\text { - high working temperature } \\
\text { - control of the surrounding environment }\end{array}$ & $\begin{array}{l}\text { benzene, butylamine, ethanol, formaldehyde, } \\
\text { hexane, hexanol, hexylamine, naphthalene, } \\
\text { trimethylamine [77-80] }\end{array}$ \\
\hline MEMS & depends on the type of sensor & $\begin{array}{l}\text { + small dimensions } \\
\text { + on-chip integration } \\
\text { + reproducible } \\
\text { - complicated fabrication process } \\
\text { - surface forces may dominate over other forces in the system } \\
\text { - controlled working environment (dust-free) } \\
\text { - development may be more costly }\end{array}$ & $\begin{array}{l}\text { diethylamine, ethanol, isopropanol, ethane, } \\
\text { methanol, propane, pentane, } \\
\text { trimethylamine [81-83] }\end{array}$ \\
\hline
\end{tabular}




\section{Commercially Available Chemical Sensors for Measurement of VOCs in Outdoor and Indoor Air}

Table 5 gathers basic information about the types of commercially available sensors for measurement of toxic gases and flammable gasses from the VOCs group and their metrological parameters. The mentioned parameters include (unless the information was unavailable): measurement range, measurement accuracy, resolution, limit of detection, sensitivity and response time.

Table 5. Commercially available chemical sensors for measurement of volatile organic compounds.

\begin{tabular}{|c|c|c|c|c|c|c|c|}
\hline Manufacturer & $\begin{array}{l}\text { Sensor } \\
\text { Type }\end{array}$ & Range & Accuracy & Resolution & LOD & Sensitivity & $\begin{array}{c}\text { Response } \\
\text { Time }\end{array}$ \\
\hline \multirow{2}{*}{ Aeroqual } & MOS & $0-500 \mathrm{ppm}$ & $< \pm 5 \mathrm{ppm}+10 \%$ & $1 \mathrm{ppm}$ & $1 \mathrm{ppm}$ & nd & $30 \mathrm{~s}$ \\
\hline & MOS & $0-25$ ppm & $< \pm 0.1 \mathrm{ppm}+10 \%$ & $0.1 \mathrm{ppm}$ & $0.1 \mathrm{ppm}$ & nd & $60 \mathrm{~s}$ \\
\hline AMS & MOS & $10-5000 \mathrm{ppm}$ & nd & nd & $10 \mathrm{ppm}$ & $0.002\left(\mathrm{R}_{\mathrm{s}} / \mathrm{R}_{\mathrm{o}}\right) / \mathrm{ppm}$ & $<10 \mathrm{~s}$ \\
\hline $\begin{array}{c}\text { Cambridge CMOS } \\
\text { Sensors }\end{array}$ & MOS & $10-400 \mathrm{ppm}$ & nd & nd & $10 \mathrm{ppm}$ & $0.005\left(\mathrm{R}_{\mathrm{s}} / \mathrm{R}_{\mathrm{o}}\right) / \mathrm{ppm}$ & nd \\
\hline SGX Snesortech & MOS & $10-500 \mathrm{ppm}$ & nd & nd & nd & $0.014\left(\mathrm{R}_{\mathrm{s}} / \mathrm{R}_{\mathrm{o}}\right) / \mathrm{ppm}$ & nd \\
\hline \multirow{2}{*}{ Alphasense } & PID & $1 \mathrm{ppb}-50 \mathrm{ppm}$ & nd & $<50 \mathrm{ppb}$ & nd & nd & $<3 \mathrm{~s}$ \\
\hline & NDIR & $0 \%-2.5 \%$ & $< \pm 500 \mathrm{ppm}$ & $<400 \mathrm{ppm}$ & $<500 \mathrm{ppm}$ & nd & $<40 \mathrm{~s}$ \\
\hline Winsen & $\mathrm{EC}$ & $0-1 \mathrm{mg} / \mathrm{dm}^{3}$ & nd & nd & nd & nd & $<20 \mathrm{~s}$ \\
\hline Winsen & $\mathrm{EC}$ & $0-10 \mathrm{ppm}$ & nd & $0.02 \mathrm{ppm}$ & nd & nd & $<60 \mathrm{~s}$ \\
\hline Citytech & $\mathrm{EC}$ & $0-14 \mathrm{ppm}$ & nd & $<0.5 \mathrm{mg} / \mathrm{m}^{3}$ & nd & nd & $<90 \mathrm{~s}$ \\
\hline Figaro & MOS & $1-100 \mathrm{ppm}$ & nd & nd & nd & $0.06\left(\mathrm{R}_{\mathrm{s}} / \mathrm{R}_{\mathrm{o}}\right) / \mathrm{ppm}$ & $30 \mathrm{~s}$ \\
\hline ION Science & PID & $\begin{array}{l}0.1-6000 \mathrm{ppm} \\
1 \mathrm{ppb}-40 \mathrm{ppm} \\
5 \mathrm{ppb}-100 \mathrm{ppm}\end{array}$ & nd & nd & $\begin{array}{l}0.1 \mathrm{ppm} \\
1 \mathrm{ppb} \\
5 \mathrm{ppb}\end{array}$ & $\begin{array}{l}25 \mathrm{mV} / \mathrm{ppm}, \\
0.7 \mathrm{mV} / \mathrm{ppm}, \\
10 \mathrm{mV} / \mathrm{ppm}\end{array}$ & $3 \mathrm{~s}$ \\
\hline Gray Wolf & PID & $0.1-10000$ ppm & nd & nd & nd & nd & $<1 \mathrm{~min}$ \\
\hline $\begin{array}{l}\text { Environmental } \\
\text { Sensors CO }\end{array}$ & EC & $0-30 \mathrm{ppm}$ & nd & $0.01 \mathrm{ppm}$ & $0.1 \mathrm{ppm}$ & nd & $60 \mathrm{~s}$ \\
\hline Z.B.P. SENSOR GAZ & pellistor & $0 \%-100 \%$ LEL & $\pm 1.5 \%$ LEL & nd & nd & $>30 \mathrm{mV} / \%$ & nd \\
\hline Figaro & pellistor & $0 \%-100 \%$ LEL & nd & nd & nd & $0.02 \mathrm{mV} / \mathrm{ppm}$ & $<30 \mathrm{~s}$ \\
\hline SGX Snesortech & pellistor & $0 \%-100 \%$ LEL & nd & nd & nd & $15 \mathrm{mV} / \%$ & $<10 \mathrm{~s}$ \\
\hline MICROcel & pellistor & $0 \%-100 \%$ LEL & nd & nd & nd & $5 \mathrm{mV} / \%$ & $<5 \mathrm{~s}$ \\
\hline Sixth Sense & pellistor & $0 \%-10 \%$ LEL & $\pm 10 \%$ LEL & nd & nd & $>25 \mathrm{mV} / \%$ & $<10 \mathrm{~s}$ \\
\hline
\end{tabular}

\section{Conclusions}

The methods of measurement of outdoor and indoor air pollutants belonging to the group of volatile organic compounds utilize broad spectrum of devices, from inexpensive chemical sensors presented in this paper to costly stationary systems such gas chromatographs, UV and IR spectrometers (including the ones with Fourier transformation), mass spectrometers, as well as electron capture detectors, flame ionization detectors, photoionization detectors and thermal conductivity detectors [84,85]. Selection of a suitable sensor depends on the gas to be measured, expected concentration range, the fact whether the sensor is meant to be stationary or portable, detect areal or point pollution, identify presence of other gases that could influence on the reading or damage the measurement device. Presented sensors are characterized by obvious advantages such as economic factor, relatively good metrological parameters, functionality, simple design, possibility of miniaturization. Nevertheless, they also possess certain limitations due to still too high limit of detection and quantification (MOS, NDIR, Pellistor, EC). Some of them also exhibit poor selective properties. That is why it is often the case that summary content of VOCs present in outdoor and indoor air is measured (PID). The chemical sensors reveal high reliability and functionality as far as personal, zone or indoor monitoring and identification of hazardous substances leaks from technological installations are concerned. This conclusion is also supported by the market, which offers wide variety of the chemical sensors for detection of flammable gases or toxic gases from the VOCs group. Progressively stricter legal rules concerning healthcare, protection of the natural environment and safety at workplace, focused on control of hazardous compounds emission beside industrial plants, power plants, transportation routes and municipal emitters such as landfills or sewage treatment plants resulted in the fact that air quality 
protection had become one of the most important elements of the ecological policy of the European Union. Despite the fact that the spectroscopic techniques are the most often applied reference methods for continuous ambient air monitoring (imision measurements), in many cases these are the chemical sensors, which are supplementary tools allowing prevention measures to be undertaken, especially in emission measurements.

Summarizing, the chemical sensors for detection and measurement of VOCs will be still developed and improved as there is an increasing market demand for them.

Acknowledgments: The investigations were financially supported by the Grant No. UMO-2015/19/B/ST4/02722 from the National Science Centre.

Author Contributions: Jacek Gębicki developed the concept and writing the manuscript. Bartosz Szulczyński made all the drawings and tables.

Conflicts of Interest: The authors declare no conflict of interest.

\section{References}

1. Lazarova, V.; Abed, B.; Markovska, G.; Dezenclos, T.; Amara, A. Control of odour nuisance in urban areas: The efficiency and social acceptance of the application of masking agents. Water Sci. Technol. 2013, 68, 614-621. [CrossRef] [PubMed]

2. Pearce, T.C.; Schiffman, S.S.; Nagle, H.T.; Gardner, J.W. Handbook of Machine Olfaction; WILEY-VCH Verlag $\mathrm{GmbH} \& \mathrm{Co} . \mathrm{KGaA}$ : Weinheim, Germany, 2003.

3. Kampa, M.; Castanas, E. Human health effects of air pollution. Environ. Pollut. 2008, 151, 362-367. [CrossRef] [PubMed]

4. Gostelow, P.; Parsons, S.A.; Stuetz, R.M. Odour measurements for sewage treatment works. Water Res. 2001, 35, 579-597. [CrossRef]

5. Taylor, S.M.; Sider, D.; Hampson, C.; Taylor, S.J.; Wilson, K.; Walter, S.D.; Eyles, J.D. Community Health Effects of a Petroleum Refinery. Ecosyst. Health 2008, 3, 27-43. [CrossRef]

6. Henshaw, P.; Nicell, J.; Sikdar, A. Parameters for the assessment of odour impacts on communities. Atmos. Environ. 2006, 40, 1016-1029. [CrossRef]

7. Daud, N.M.; Sheikh Abdullah, S.R.; Abu Hasan, H.; Yaakob, Z. Production of biodiesel and its wastewater treatment technologies: A review. Process Saf. Environ. Prot. 2014, 94, 487-508. [CrossRef]

8. Yan, L.; Wang, Y.; Li, J.; Ma, H.; Liu, H.; Li, T.; Zhang, Y. Comparative study of different electrochemical methods for petroleum refinery wastewater treatment. Desalination 2014, 341, 87-93. [CrossRef]

9. Yavuz, Y.; Koparal, A.S.; Ogutveren, U.B. Treatment of petroleum refinery wastewater by electrochemical methods. Desalination 2010, 258, 201-205. [CrossRef]

10. Capelli, L.; Sironi, S.; Barczak, R.; Il Grande, M.; del Rosso, R. Validation of a method for odor sampling on solid area sources. Water Sci. Technol. 2012, 66, 1607-1613. [PubMed]

11. Bokowa, A.H. Review of odour legislation. Chem. Eng. Trans. 2010, 23, 31-36. [CrossRef]

12. Trincavelli, M.; Coradeschi, S.; Loutfi, A. Odour classification system for continuous monitoring applications. Sens. Actuator B Chem. 2009, 139, 265-273. [CrossRef]

13. Ilgen, E.; Karfich, N.; Levsen, K.; Angerer, J.; Schneider, P.; Heinrich, J.; Wichmann, H.E.; Dunemann, L.; Begerow, J. Aromatic hydrocarbons in the atmospheric environment: Part I. Indoor versus outdoor sources, the influence of traffic. Atmos. Environ. 2001, 35, 1235-1252. [CrossRef]

14. Chao, C.Y.H. Comparison between indoor and outdoor air contaminant levels in residential buildings from passive sampler study. Build. Environ. 2001, 36, 999-1007. [CrossRef]

15. Righi, E.; Aggazzotti, G.; Fantuzzi, G.; Ciccarese, V.; Predieri, G. Air quality and well-being perception in subjects attending university libraries in Modena (Italy). Sci. Total Environ. 2002, 286, 41-50.

16. Chan, A.T. Indoor-outdoor relationships of particulate matter and nitrogen oxides under different outdoor meteorological conditions. Atmos. Environ. 2002, 36, 1543-1551. [CrossRef]

17. Kot-Wasik, A.; Zabiegała, B.; Urbanowicz, M.; Dominiak, E.; Wasik, A.; Namieśnik, J. Advances in passive sampling in environmental studies. Anal. Chim. Acta 2007, 602, 141-163. [CrossRef] [PubMed]

18. Partyka, M.; Zabiegała, B.; Namieśnik, J.; Przyjazny, A. Application of Passive Samplers in Monitoring of Organic Constituents of Air. Crit. Rev. Anal. Chem. 2007, 37, 51-77. [CrossRef] 
19. Weschler, C.J. Changes in indoor pollutants since the 1950s. Atmos. Environ. 2009, 43, 153-169. [CrossRef]

20. Zabiegała, B.; Partyka, M.; Zygmunt, B.; Namieśnik, J. Determination of volatile organic compounds in indoor air in the Gdansk area using permeation passive samplers. Indoor Built Environ. 2009, 18, 492-504. [CrossRef]

21. World Health Organization Publications. Air Quality Guidelines for Europe; European Series No. 91; World Health Organization: Copenhagen, Denmark, 2000.

22. Stetter, J.R.; Li, J. Amperometric gas sensors-A review. Chem. Rev. 2008, 108, 352-366. [CrossRef] [PubMed]

23. Rock, F.; Barsan, N.; Weimar, U. Electronic nose: Current status and future trends. Chem. Rev. 2008, 108, 705-725. [CrossRef] [PubMed]

24. Gebicki, J. Application of electrochemical sensors and sensor matrixes for measurement of odorous chemical compounds. Trac Trends Anal. Chem. 2016, 77, 1-13. [CrossRef]

25. Drager Technik fur das Leben, 2015. Available online: www.draeger.com (accessed on 15 August 2015).

26. Gebicki, J.; Dymerski, T. Application of Chemical Sensors and Sensor Matrixes to Air Quality Evaluation. In The Quality of Air, 1st ed.; de la Guardia, M., Armenta, S., Eds.; Elsevier: Amsterdam, The Netherlands, 2016; Volume 73, pp. 267-294.

27. Cao, Z.; Buttner, W.J.; Stetter, J.R. The properties and applications of amperometric gas sensors. Electroanalysis 1992, 4, 253-266. [CrossRef]

28. Bontempelli, G.; Comisso, N.; Toniolo, R.; Schiavon, G. Electroanalytical sensors for nonconducting media based on electrodes supported on perfluorinated ion-exchange membranes. Electroanalysis 1997, 9, 433-443. [CrossRef]

29. Chang, J.F.; Kuo, H.H.; Leu, I.C.; Hon, M.H. The effects of thickness and operation temperature on $\mathrm{ZnO}: \mathrm{Al}$ thin film CO gas sensor. Sens. Actuator B Chem. 2002, 84, 258-264. [CrossRef]

30. Sakai, G.; Baik, N.S.; Miura, N.; Yamazoe, N. Gas sensing properties of tin oxide thin films fabricated from hydrothermally treated nanoparticles: Dependence of $\mathrm{CO}$ and $\mathrm{H}_{2}$ response on film thickness. Sens. Actuator B Chem. 2001, 77, 116-121. [CrossRef]

31. Galdikas, A.; Mironas, A.; Setkus, A. Copper-doping level effect on sensitivity and selectivity of tin oxide thin-film gas sensor. Sens. Actuator B Chem. 1995, 26, 29-32. [CrossRef]

32. Yamazoe, N.; Sakai, G.; Shimanoe, K. Oxide semiconductor gas sensors. Catal. Surv. Asia 2003, 7, 63-75. [CrossRef]

33. Emelin, E.V.; Nikolaev, I.N. Sensitivity of MOS sensors to hydrogen, hydrogen sulfide, and nitrogen dioxide in different gas atmospheres. Meas. Tech. 2006, 49, 524-528. [CrossRef]

34. Berna, A. Metal Oxide Sensors for Electronic Noses and Their Application to Food Analysis. Sensors 2010, 10, 3882-3910. [CrossRef] [PubMed]

35. Arshak, K.; Moore, E.; Lyons, G.M.; Harris, J.; Clifford, S. A review of gas sensors employed in electronic nose applications. Sens. Rev. 2004, 24, 181-198. [CrossRef]

36. Munoz, R.; Sivret, E.C.; Parcsi, G.; Lebrero, R.; Wang, X.; Suffet, I.H.; Stuetz, R.M. Monitoring techniques for odour abatement assessment. Water Res. 2010, 44, 5129-5149. [CrossRef] [PubMed]

37. Brzózka, Z.; Wróblewski, W. Sensory Chemiczne; Oficyna Wydawnicza Politechniki Warszawskiej: Warsaw, Poland, 1998.

38. Wilson, A.D.; Baietto, M. Applications and advances in electronic-nose technologies. Sensors 2009, 9, 5099-5148. [PubMed]

39. Stetter, J.R.; Penrose, W.R. Understanding Chemical Sensors and Chemical Sensor Arrays (Electronic Noses): Past, Present, and Future. Sens. Update 2002, 10, 189-229. [CrossRef]

40. Wilson, A.D. Review of Electronic-nose Technologies and Algorithms to Detect Hazardous Chemicals in the Environment. Procedia Technol. 2012, 1, 453-463. [CrossRef]

41. Boeker, P. On “Electronic Nose” methodology. Sens. Actuator B Chem. 2014, 204, 2-17. [CrossRef]

42. Nicolas, J.; Romain, A.C. Establishing the limit of detection and the resolution limits of odorous sources in the environment for an array of metal oxide gas sensors. Sens. Actuator B Chem. 2004, 99, 384-392. [CrossRef]

43. Sohn, J.H.; Hudson, N.; Gallagher, E.; Dunlop, M.; Zeller, L.; Atzeni, M. Implementation of an electronic nose for continuous odour monitoring in a poultry shed. Sens. Actuator B Chem. 2008, 133, 60-69. [CrossRef]

44. Dentoni, L.; Capelli, L.; Sironi, S.; Rosso, R.; Zanetti, S.; Della Torre, M. Development of an Electronic Nose for Environmental Odour Monitoring. Sensors 2012, 12, 14363-14381. [CrossRef] [PubMed] 
45. Albert, K.J.; Lewis, N.S.; Schauer, C.L.; Sotzing, G.A.; Stitzel, S.E.; Vaid, T.P.; Walt, D.R. Cross-Reactive Chemical Sensor Arrays. Chem. Rev. 2000, 100, 2595-2626. [CrossRef] [PubMed]

46. Munoz, B.C.; Steinthal, G.; Sunshine, S. Conductive polymer-carbon black composites-based sensor arrays for use in an electronic nose. Sens. Rev. 1999, 19, 300-305. [CrossRef]

47. Briglin, S.M.; Freund, M.S.; Tokumaru, P.; Lewis, N.S. Exploitation of spatiotemporal information and geometric optimization of signal/noise performance using arrays of carbon black-polymer composite vapor detectors. Sens. Actuator B Chem. 2002, 82, 54-74. [CrossRef]

48. Partridge, A.C.; Jansen, M.L.; Arnold, W.M. Conducting polymer-based sensors. Mater. Sci. Eng. C 2000, 12, 37-42. [CrossRef]

49. Bai, H.; Li, C.; Chen, F.; Shi, G. Aligned three-dimensional microstructures of conducting polymer composites. Polymer 2007, 48, 5259-5267. [CrossRef]

50. Bai, H.; Shi, G. Gas Sensors Based on Conducting Polymers. Sensors 2007, 7, 267-307.

51. Gebicki, J.; Kloskowski, A.; Chrzanowski, W.; Stepnowski, P.; Namiesnik, J. Application of Ionic Liquids in Amperometric Gas Sensors. Crit. Rev. Anal. Chem. 2016, 46, 122-138. [CrossRef] [PubMed]

52. Gebicki, J. Application of ionic liquids in electronic nose instruments. In Analytical Applications of Ionic Liquids; Koel, M., Ed.; World Scientific Publishing Europe Ltd.: London, UK, 2016; pp. 339-360.

53. English, J.T.; Bavana, A.D.; Freund, M.S. Biogenic amine vapour detection using poly (anilineboronic acid) films. Sens. Actuator B Chem. 2006, 115, 666-671. [CrossRef]

54. Li, B.; Santhanam, S.; Schultz, L.; Jeffries-EL, M.; Iovu, M.C.; Sauve, G.; Cooper, J.; Zhang, R.; Revelli, J.C.; Kusne, A.G.; et al. Inkjet printed chemical sensor array based on polythiophene conductive polymers. Sens. Actuator B Chem. 2007, 123, 651-660. [CrossRef]

55. Wang, F.; Yang, Y.; Swager, T.M. Molecular recognition for high selectivity in carbon nanotube/ polythiophenechemiresistors. Angew. Chem. 2008, 120, 8522-8524. [CrossRef]

56. Lipatov, A.; Varezhnikov, A.; Wilson, P.; Sysoev, V.; Kolmakov, A.; Sinitskii, A. Highly selective gas sensor arrays based on thermally reduced grapheneoxide. Nanoscale 2013, 5, 5426-5434. [CrossRef] [PubMed]

57. Zito, C.A.; Perfecto, T.M.; Volanti, D.P. Impact of reduced graphene oxide on the ethanol sensing performance of hollow $\mathrm{SnO}_{2}$ nanoparticles under humid atmosphere. Sens. Actuator B Chem. 2017, 244, 466-474. [CrossRef]

58. Tasaltin, C.; Basarir, F. Preparation of flexible VOC sensor based on carbon nanotubes and gold nanoparticles. Sens. Actuator B Chem. 2014, 194, 173-179. [CrossRef]

59. Castro, M.; Kumar, B.; Feller, J.F.; Haddi, Z.; Amari, A.; Bouchikhi, B. Novel e-nose for the discrimination of volatile organic biomarkers with an array of carbon nanotubes (CNT) conductive polymer nanocomposites (CPC) sensors. Sens. Actuator B Chem. 2011, 159, 213-219. [CrossRef]

60. Kumar, B.; Castro, M.; Feller, J.F. Poly(lactic acid)-multi-wall carbon nanotube conductive biopolymer nanocomposite vapour sensors. Sens. Actuator B Chem. 2012, 161, 621-628. [CrossRef]

61. Athawale, A.A.; Bhagwat, S.V.; Katre, P.P. Nanocomposite of Pd-polyaniline as a selective methanol sensor. Sens. Actuator B Chem. 2006, 114, 263-267. [CrossRef]

62. Santhanam, K.S.V.; Sangoi, R.; Fuller, L. A chemical sensor for chloromethanes using a nanocomposite of multiwalled carbon nanotubes with poly (3-methylthiophene). Sens. Actuator B Chem. 2005, 106, 766-771.

63. Sharma, S.; Nirkhe, C.; Prthkar, S.; Athawale, A.A. Chloroform vapour sensor based on copper/polyaniline nanocomposite. Sens. Actuator B Chem. 2002, 85, 131-136. [CrossRef]

64. Sayago, I.; Fernandez, M.J.; Fontecha, J.L.; Horrilli, M.C.; Vera, C.; Obieta, I.; Bustero, I. Surface acoustic wave gas sensors based on polyisobutylene and carbon nanotube composites. Sens. Actuator B Chem. 2011, 156, 1-5. [CrossRef]

65. Penza, M.; Antolini, F.; Antisari, M.V. Carbon nanotubes as SAW chemical sensors materials. Sens. Actuator B Chem. 2004, 100, 47-59. [CrossRef]

66. Sayago, I.; Fernandez, M.J.; Fontecha, J.L.; Horillo, M.C.; Vera, C.; Obieta, I.; Bustero, I. New sensitive layers for surface acoustic wave gas sensors based on polymer and carbon nanotube composites. Sens. Actuator B Chem. 2012, 175, 67-72. [CrossRef]

67. Viespe, C.; Grigoriu, C. Surface acoustic wave sensors with carbon nanotubes and $\mathrm{SiO}_{2} / \mathrm{Si}$ nanoparticles based nanocomposites for VOC detection. Sens. Actuator B Chem. 2010, 147, 43-47. [CrossRef]

68. Crawford, M.; Stewart, G.; McGregor, G.; Gilchrist, J.R. Design of a portable optical sensor for methane gas detection. Sens. Actuator B Chem. 2006, 113, 830-836. 
69. Goncalves, V.C.; Balogh, D.T. Optical chemical sensors using polythio-phene derivatives as active layer for detection of volatile organic compounds. Sens. Actuator B Chem. 2012, 162, 307-312. [CrossRef]

70. Elosua, C.; Arregui, F.J.; Zamarreño, C.R.; Bariain, C.; Luquin, A.; Laguna, M.; Mati, I.R. Volatile organic compounds optical fiber sensor based on lossy mode resonances. Sens. Actuator B Chem. 2012, 173, 523-529. [CrossRef]

71. Nizamidin, P.; Yimit, A.; Abdurrahman, A.; Itoh, K. Formaldehyde gas sensor based on silver-and-yttrium-co doped-lithium iron phosphate thin film optical waveguide. Sens. Actuator B Chem. 2013, 176, 460-466. [CrossRef]

72. Martínez-Hurtado, J.L.; Davidson, C.A.B.; Blyth, J.; Lowe, C.R. Holographic detection of hydrocarbon gases and other volatile organic compounds. Langmuir 2010, 26, 15694-15699. [CrossRef] [PubMed]

73. Wales, D.J.; Parker, R.M.; Quainoo, P.; Cooper, P.A.; Gates, J.C.; Grossel, M.C.; Smith, P.G.R. An integrated optical Bragg grating refractometer for volatile organic compound detection. Sens. Actuator B Chem. 2016, 282, 595-604. [CrossRef]

74. Khot, L.R.; Panigrahi, S.; Lin, D. Development and evaluation of piezoelectric-polymer thin film sensors for low concentration detection of volatile organic compounds related to food safety applications. Sens. Actuator B Chem. 2011, 153, 1-10. [CrossRef]

75. Si, P.; Mortensen, J.; Komolov, A.; Denborg, J.; Møller, P.J. Polymer coated quartz crystal microbalance sensors for detection of volatile organic compounds in gas mixtures. Anal. Chim. Acta 2007, 597, 223-230. [CrossRef] [PubMed]

76. Rizzo, S.; Sannicolo, F.; Benincori, T.; Schiavon, G.; Zecchin, S.; Zotti, G. Calix[4]arene-functionalized poly-cyclopenta[2,1-b;3,4-b]bithiophenes with good recognition ability and selectivity for small organic molecules for application in QCM-based sensors. J. Mater. Chem. 2004, 14, 1804-1811. [CrossRef]

77. Chang, J.B.; Liu, V.; Subramanian, V.; Sivula, K.; Luscombe, C.; Murphy, A.; Liu, J.; Fréchet, J.M.J. Printable polythiophene gas sensor array for low-cost electronic noses. J. Appl. Phys. 2006, 100, 14506-14507. [CrossRef]

78. Liao, F.; Yin, S.; Toney, M.F.; Subramanian, V. Physical discrimination ofamine vapor mixtures using polythiophene gas sensor arrays. Sens. Actuator B Chem. 2010, 150, 254-263. [CrossRef]

79. Andersson, M.; Bastuck, M.; Huotari, L.; Lloyd Spetz, A.; Lappalainen, J.; Schütze, A.; Puglisi, D. SiC-FET Sensors for Selective and Quantitative Detection of VOCs Down to Ppb Level. Procedia Eng. 2016, 168, 216-220. [CrossRef]

80. Bur, C.; Bastuck, M.; Puglisi, D.; Schütze, A.; Lloyd Spetz, A.; Andersson, M. Discrimination and quantification of volatile organic compounds in the ppb-range with gas sensitive SiC-FETs using multivariate statistics. Sens. Actuator B Chem. 2015, 514, 225-233. [CrossRef]

81. Pandya, H.J.; Chandra, S.; Vyas, A.L. Integration of ZnO nanostructures with MEMS for ethanol sensor. Sens. Actuator B Chem. 2012, 161, 923-928. [CrossRef]

82. Pohle, R.; Weisbrod, E.; Hedler, H. Enhancement of MEMS-based $\mathrm{Ga}_{2} \mathrm{O}_{3}$ Gas Sensors by Surface Modifications. Procedia Eng. 2016, 168, 211-215. [CrossRef]

83. Kilinc, N.; Cakmak, O.; Kosemen, A.; Ermek, E.; Ozturk, S.; Yerli, Y.; Ozturk, Z.Z.; Urey, H. Fabrication of $1 \mathrm{D} \mathrm{ZnO}$ nanostructures on MEMS cantilever for VOC sensor application. Sens. Actuator B Chem. 2014, 202, 357-364. [CrossRef]

84. Williams, M.L. Monitoring of exposure to air pollution. Sci. Total. Environ. 1995, 168, 169-174. [CrossRef]

85. Strang, C.R.; Levine, S.P.; Herget, W.F. A preliminary evaluation of the Fourier transform infrared (FTIR) spectrometer as a quantitative air monitor for semiconductor manufacturing process emissions. Am. Ind. Hyg. Assoc. J. 1989, 50, 70-77. [CrossRef]

(C) 2017 by the authors. Licensee MDPI, Basel, Switzerland. This article is an open access article distributed under the terms and conditions of the Creative Commons Attribution (CC BY) license (http://creativecommons.org/licenses/by/4.0/). 